\title{
Knowledge and Attitude of Dentists Regarding Patients Undergoing Bisphosphonate Treatment: a Comparative Questionnaire
}

\author{
Ioana-Aurița Albu-Stan¹, Cecilia Petrovan², Diana Cerghizan¹, Lia Yero Eremie1, Adriana Elena \\ Crăciun', Constantin Copotoiu ${ }^{3}$ \\ 1 Department of Fixed Prosthodontics, University of Medicine and Pharmacy, Tîrgu Mureș, Romania \\ 2 Department of Oral and Maxillofacial Surgery, University of Medicine and Pharmacy, Tîrgu Mureș, Romania \\ 3 Department of Surgery, University of Medicine and Pharmacy, Tîrgu Mureș, Romania
}

\section{CORRESPONDENCE}

\section{Adriana Elena Crăciun}

Str. Gheorghe Marinescu nr. 38

540099 Tîrgu Mures, Romania

Tel: +40 265215551

E-mail: craciun.adriana92@yahoo.com

\section{ARTICLE HISTORY}

Received: June 12, 2018

Accepted: July 28, 2018
Ioana-Aurita Albu-Stan • Str. Gheorghe Marinescu nr. 38, 540139 Tîrgu Mures, Romania. Tel: +40 0265 215551

Cecilia Petrovan - Str. Gheorghe Marinescu nr. 38 540139 Tîrgu Mureș, Romania. Tel: +40 0265215551 Diana Cerghizan • Str. Gheorghe Marinescu nr. 38 540139 Tîrgu Mureș, Romania. Tel: +40 0265215551 Lia Yero Eremie • Str. Gheorghe Marinescu nr. 38 , 540139 Tîrgu Mureș, Romania. Tel: +40 026521555

Constantin Copotoiu • Str. Gheorghe Marinescu nr. 38, 540139 Tîrgu Mures, Romania. Tel: +40 0265 215551

\section{ABSTRACT}

Background: Osteonecrosis of the jaw is an uncommon but serious complication related to oral and intravenous bisphosphonate (BP) therapy. Its pathogenesis is not well understood, and there are no universal protocols accepted to treat it. The aim of our study was to use the same questionnaire as four years ago to evaluate the awareness of dentists in Tîrgu Mureș regarding the dental treatments that can be applied in patients on BP therapy, and to assess how their knowledge on the subject has evolved over these years. Material and method: We used the same questionnaire-based study as four years ago among dentists in Tîrgu Mureș, raising important issues such as: is the patient asked about current or previous treatments with BPs, do they perform surgical treatment in these patients, do they know under what conditions they can perform this treatment, or do they deem it necessary to contact the prescriber before surgical treatment. Results: One-hundred twenty questionnaires were returned. The majority of respondents $(n=113,94.2 \%$ ) included the question regarding the use of BPs in their medical records. Of all respondents, 48 (40\%) perform dental or surgical treatments on patients undergoing BP therapy, 68 (56.7\%) do not perform dental or surgical treatments on these patients, and four of the respondents (3.3\%) did not know the answer. One hundred (83.3\%) respondents always contact the prescriber prior to surgery in these patients, regardless of how BPs are administered. Conclusions: According to the findings of the present study, many of the respondent doctors have heard about BPs and their complications, but they are not aware of the fundamental concepts of bisphosphonate-related osteonecrosis of the jaw prevention and treatment protocols. In the absence of appropriate protocols, the quality of life of these patients is compromised.

Keywords: osteonecrosis, jaw, bisphosphonates, surgery, quality of life 


\section{INTRODUCTION}

Bisphosphonate-related osteonecrosis of the jaw (BRONJ) is an uncommon but serious complication, reported for the first time by Marx in 2003. ${ }^{1}$ BRONJ is defined as necrotic bone exposed in the maxillofacial region for at least eight weeks with no signs of healing in patients treated with bisphosphonates (BPs) and without head and neck radiation therapy in the present or the past. ${ }^{2}$ BPs are used in the treatment of Paget's disease, multiple myeloma, as well as osteolytic lesions associated with bony metastases and is the most prescribed therapy against osteoporotic pathology.

Due to the fact that BPs are not metabolized and accumulate in the bone, the osteoclastic activity is interrupted by other inhibitors, such as denosumab and bevacizumab, and under conditions of bone trauma, the osteonecrosis of the jaw is likely to be triggered. The uncontrolled therapeutic effect of monoclonal antibodies and BPs in reducing osteoclast function may lead to osteonecrosis when a critical limit of at least $50 \%$ of the total cell mass is reached. ${ }^{3}$

Various studies attempted to elucidate why BP treatment complications, such as inhibition of angiogenesis and apoptosis of osteoclasts, inhibition of bone remodeling and bone turnover, inflammation, infection, or the vast variety of microorganisms in the oral flora, occur only at the level of the oral cavity. ${ }^{4-10}$

The actual incidence of BRONJ is uncertain; it depends on treatment indication, sample size, and the studied population, and varies from $0.028 \%$ to $18.6 \% .^{11,12}$

Administering BPs via the intravenous route has a higher risk of developing BRONJ, although oral treatment longer than three years may also increase this risk. ${ }^{2}$

A frequent trigger factor is represented by dentoalveolar procedures in patients undergoing intravenous BP treatment. They are at least seven times more likely to develop osteonecrosis of the jaw than those who underwent intravenous BP treatment but are not subject to dentoalveolar surgery. ${ }^{13}$

Our study is focused on BRONJ, although other medications (denosumab, bevacizumab, cabozantinib, sunitinib) have also been associated with jaw osteonecrosis in 2014 by the special committee of American Association of Oral and Maxillofacial Surgeons (AAOMS), who called this condition medication-related osteonecrosis of the jaw (MRONJ). ${ }^{14}$

In 2014, we carried out a questionnaire-based study among dentists in Tîrgu Mureș. ${ }^{15}$ At present, in June 2018, we intended to use the same questionnaire and assess how the dentists' knowledge regarding dental treatments in patients with current or previous BP therapy has evolved over these four years.

\section{MATERIAL AND METHOD}

In June 2018, we carried out a questionnaire-based study among dentists in Tîrgu Mureș. The questionnaire consisted of the same 13 questions included in the previous study, conducted in 2014.

A total of 26 questionnaires were handed personally to clinicians within the Faculty of Dentistry of Tîrgu Mureș, and the others were sent to dental practitioners using social networks. The respondents were dentists, residents, and specialists, who were asked to choose one of the answers for every question. We asked whether the respondents were residents or medical specialists in a branch of dentistry. We also asked whether they had knowledge about BPs and whether they deem it necessary to ask their patients about current or previous BP treatments.

We considered it important to ask whether the respondents knew that they performed dental treatments/dentoalveolar surgery in patients who are/were treated with BPs and whether they know under what conditions they can perform tooth extractions or other dentoalveolar surgical treatments in patients treated with BPs.

An important aspect of the questionnaire was whether the respondents contacted the prescriber before performing a tooth extraction or dentoalveolar surgical treatment on a patient.

Statistical analysis was not carried out, as it was considered that it would not be helpful due to the large number of variants.

\section{RESULTS}

The questionnaires were completed and returned by 120 respondent clinicians. The results are presented and compared with those from the 2014 study in Table 1.

\section{DISCUSSIONS}

In the last years, the number of BRONJ cases reported in the literature has increased. ${ }^{16-19}$ As far as we know, no study has been conducted in Romania yet to investigate the degree of dentists' knowledge about BRONJ.

The present study was developed in order to evaluate the awareness of dentists in Tîrgu Mureș using the same questionnaire we used four years ago, and to determine whether their knowledge regarding BRONJ has improved in these four years. 
TABLE 1. Comparison between questionnaire response distribution in 2018 vs. 2014

\begin{tabular}{|c|c|c|c|c|}
\hline No. & Question & Answers & $\begin{array}{l}\text { Responses from } \\
2014,70 \text { respon- } \\
\text { dents }\end{array}$ & $\begin{array}{l}\text { Responses from } \\
2018,120 \text { respon- } \\
\text { dents }\end{array}$ \\
\hline 1. & $\begin{array}{l}\text { For how long have you been practicing } \\
\text { dentistry? }\end{array}$ & $\begin{array}{l}\text { a) less than three years } \\
\text { b) three-six years } \\
\text { c) more than six years }\end{array}$ & $\begin{array}{l}\text { a) } 27.14 \% \\
\text { b) } 32.86 \% \\
\text { c) } 40 \%\end{array}$ & $\begin{array}{l}\text { a) } 35 \% \\
\text { b) } 26.66 \% \\
\text { c) } 38.34 \%\end{array}$ \\
\hline 2. & $\begin{array}{l}\text { Are you a resident doctor in a branch of den- } \\
\text { tistry? }\end{array}$ & $\begin{array}{l}\text { a) no } \\
\text { b) resident in dentoalveolar surgery/maxillofa- } \\
\text { cial surgery } \\
\text { c) other branches, please specify ................ }\end{array}$ & $\begin{array}{l}\text { a) } 77.14 \% \\
\text { b) } 7.14 \% \\
\text { c) } 15.72 \%\end{array}$ & $\begin{array}{l}\text { a) } 90 \% \\
\text { b) } 4.17 \% \\
\text { c) } 5.83 \%\end{array}$ \\
\hline 3. & $\begin{array}{l}\text { Do you have a specialty in a branch of den- } \\
\text { tistry? }\end{array}$ & $\begin{array}{l}\text { a) no } \\
\text { b) specialty in dentoalveolar surgery/maxillofa- } \\
\text { cial surgery } \\
\text { c) other branches, please specify ................ }\end{array}$ & $\begin{array}{l}\text { a) } 47.37 \% \\
\text { b) } 15.79 \% \\
\text { c) } 36.84 \%\end{array}$ & $\begin{array}{l}\text { a) } 69.17 \% \\
\text { b) } 13.33 \% \\
\text { c) } 17.5 \%\end{array}$ \\
\hline 4. & $\begin{array}{l}\text { Have you heard about bisphosphonate treat- } \\
\text { ment? }\end{array}$ & $\begin{array}{l}\text { a) no } \\
\text { b) yes }\end{array}$ & $\begin{array}{l}\text { a) } 17.14 \% \\
\text { b) } 82.86 \%\end{array}$ & $\begin{array}{l}\text { a) } 3.33 \% \\
\text { b) } 96.67 \%\end{array}$ \\
\hline 5. & $\begin{array}{l}\text { Do you know in which pathology/pathologies is } \\
\text { this treatment recommended? }\end{array}$ & $\begin{array}{l}\text { a) no } \\
\text { b) yes, please specify ............... }\end{array}$ & $\begin{array}{l}\text { a) } 25.71 \% \\
\text { b) } 74.29 \%\end{array}$ & $\begin{array}{l}\text { a) } 5.83 \% \\
\text { b) } 94.17 \%\end{array}$ \\
\hline 6. & $\begin{array}{l}\text { Do you ask about treatments with bisphospho- } \\
\text { nates while completing the patient's medical } \\
\text { history? }\end{array}$ & $\begin{array}{l}\text { a) no } \\
\text { b) yes } \\
\text { c) not relevant in dentistry practice }\end{array}$ & $\begin{array}{l}\text { a) } 38.57 \% \\
\text { b) } 60 \% \\
\text { c) } 1.43 \%\end{array}$ & $\begin{array}{l}\text { a) } 5.83 \% \\
\text { b) } 94.17 \% \\
\text { c) } 0 \%\end{array}$ \\
\hline 7. & $\begin{array}{l}\text { Have you performed dental treatments/ dento- } \\
\text { alveolar surgery on a patient who was under/ } \\
\text { has received bisphosphonate treatment? }\end{array}$ & $\begin{array}{l}\text { a) no } \\
\text { b) yes } \\
\text { c) I do not know }\end{array}$ & $\begin{array}{l}\text { a) } 42.85 \% \\
\text { b) } 34.29 \% \\
\text { c) } 22.86 \%\end{array}$ & $\begin{array}{l}\text { a) } 56.67 \% \\
\text { b) } 40 \% \\
\text { c) } 3.33 \%\end{array}$ \\
\hline 8. & $\begin{array}{l}\text { Do you know whether complications of } \\
\text { bisphosphonate treatment occur only in the } \\
\text { oral cavity or in other parts of the body as well? }\end{array}$ & $\begin{array}{l}\text { a) no } \\
\text { b) yes }\end{array}$ & $\begin{array}{l}\text { a) } 41.43 \% \\
\text { b) } 58.57 \%\end{array}$ & $\begin{array}{l}\text { a) } 20.83 \% \\
\text { b) } 79.17 \%\end{array}$ \\
\hline 9. & $\begin{array}{l}\text { Do you know what kind of manifestations occur } \\
\text { in the oral cavity after treatment with bisphos- } \\
\text { phonates? }\end{array}$ & $\begin{array}{l}\text { a) no } \\
\text { b) yes }\end{array}$ & $\begin{array}{l}\text { a) } 25.71 \% \\
\text { b) } 74.29 \%\end{array}$ & $\begin{array}{l}\text { a) } 15.83 \% \\
\text { b) } 84.17 \%\end{array}$ \\
\hline 10. & $\begin{array}{l}\text { Do you know under what conditions you can } \\
\text { perform tooth extractions or other dentoalveo- } \\
\text { lar surgical treatments on patients treated with } \\
\text { bisphosphonates? }\end{array}$ & $\begin{array}{l}\text { a) no } \\
\text { b) yes } \\
\text { c) not relevant in dentistry practice }\end{array}$ & $\begin{array}{l}\text { a) } 48.57 \% \\
\text { b) } 50 \% \\
\text { c) } 1.43 \%\end{array}$ & $\begin{array}{l}\text { a) } 11.67 \% \\
\text { b) } 85 \% \\
\text { c) } 3.33 \%\end{array}$ \\
\hline 11. & $\begin{array}{l}\text { Do you contact the prescriber before surgery in } \\
\text { a patient that needs a tooth extraction or other } \\
\text { dentoalveolar surgery and is under bisphos- } \\
\text { phonate treatment? }\end{array}$ & $\begin{array}{l}\text { a) no } \\
\text { b) yes } \\
\text { c) not relevant in dentistry practice }\end{array}$ & $\begin{array}{l}\text { a) } 12.86 \% \\
\text { b) } 85.71 \% \\
\text { c) } 1.43 \%\end{array}$ & $\begin{array}{l}\text { a) } 10 \% \\
\text { b) } 86.67 \% \\
\text { c) } 3.33 \%\end{array}$ \\
\hline 12. & $\begin{array}{l}\text { Do you think there are differences between the } \\
\text { complications that occur after treatment with } \\
\text { bisphosphonates administered intravenously } \\
\text { or orally? }\end{array}$ & $\begin{array}{l}\text { a) no } \\
\text { b) yes }\end{array}$ & $\begin{array}{l}\text { a) } 40 \% \\
\text { b) } 60 \%\end{array}$ & $\begin{array}{l}\text { a) } 34.17 \% \\
\text { b) } 65.83 \%\end{array}$ \\
\hline 13. & $\begin{array}{l}\text { Do you contact the prescriber before surgery in } \\
\text { a patient who needs a tooth extraction or other } \\
\text { dentoalveolar surgery and is under bisphos- } \\
\text { phonate treatment administered intravenously } \\
\text { or orally? }\end{array}$ & $\begin{array}{l}\text { a) I do not contact the prescriber } \\
\text { b) I contact the prescriber only in case of oral } \\
\text { administration } \\
\text { c) I contact the prescriber only in case of intra- } \\
\text { venous administration } \\
\text { d) I always contact the prescriber }\end{array}$ & $\begin{array}{l}\text { a) } 12.86 \% \\
\text { b) } 0 \% \\
\text { c) } 4.28 \% \\
\text { d) } 82.86 \%\end{array}$ & $\begin{array}{l}\text { a) } 11.67 \% \\
\text { b) } 0 \% \\
\text { c) } 5 \% \\
\text { d) } 83.33 \%\end{array}$ \\
\hline
\end{tabular}

The majority of respondents (38.34\%) had a dental practice for more than six years, and most of them (96.67\%) heard about BP therapy, representing a $13.81 \%$ increase compared to the responses received in 2014. Regarding the pathologies recommended to be treated with BPs, most of the respondents (15.7\%) mentioned osteoporo- sis, $5.8 \%$ bone tumors, $4.1 \%$ bone metastases, and $1.65 \%$ mentioned chemotherapy. None of the respondents were aware of the use of BPs in the treatment of Paget's disease. In the 2014 study, 5.81\% knew about Paget's disease and multiple myeloma, and they recognized osteoporosis as the main pathology to benefit from these drugs in a higher 
percentage (55.82\%). None of the dentists who responded to the questionnaire in 2014 and 2018 knew about the usage of BPs in the treatment of malignant hypercalcemia and osteogenesis imperfecta. Dentists should know the mechanism of action of BPs due to their adverse effects: bone turnover is reduced, and the function of osteoclasts is inhibited, which leads to the reduction of bone remodeling. ${ }^{2,20}$ The consequent necrosis of bone cells appears due to the inhibition of angiogenesis, another mechanism of action of BPs. ${ }^{2,5,14}$ The dentists' knowledge will influence the attention given to the patient, the way they draw up the patients' medical file, whether they ask about or recognize the medication. The majority of the respondents (94.17\%) ask about a possible treatment with BPs while completing the patients' medical history. This is a step forward for the early identification of possible complications, especially as there is a significant increase from the 2014 questionnaire, where only $60 \%$ of the respondents had this question in their anamnesis.

In question number seven, a small percentage (3.33\%) of respondents did not know if they performed surgical or dental treatments in patients who are/were treated with BPs. This percentage decreased compared to $22.86 \%$ obtained in the 2014 questionnaire.

A percentage of $20.83 \%$ said they do not know if BP treatment complications occur only in the mouth. Dentists should be aware of the manifestations of BRONJ and their preferred area of occurence. BRONJ is more common in the posterior mandible than the maxilla, in a ratio of $2: 1 .^{2}$

It is critical for dentists to be prepared to treat these patients appropriately. Dentoalveolar surgeries represent the main local risk factors for BRONJ, especially tooth extraction acts as a trigger point in the development of BRONJ. Periodontal diseases and denture use are also considered potential risk factors. ${ }^{2,14}$

Our study revealed that $11.67 \%$ of the respondents do not know under what conditions they can perform tooth extractions or other dentoalveolar surgical treatments on patients treated with BPs, and $3.33 \%$ considered the subject is not relevant for dentistry practice.

Besides dental procedures, BRONJ is related to trauma to the mouth caused by incorrectly adjusted prostheses, oral infection, poor oral hygiene, diabetes, and smoking. ${ }^{9,21-24}$

The percentage of respondents who contact the prescribing physician before carrying out a tooth extraction or other dentoalveolar surgery in a patient with BP treatment was similar in 2014 and $2018,85.71 \%$ and $86.67 \%$ respectively.
About one-third of the respondents, $34.17 \%$, said there is no difference between the oral or intravenous administration of BPs, but according to studies, the route of administration affects the skeleton differently. Oral BPs are poorly absorbed and present less than one percent of bioavailability, whereas BPs administered intravenously have maximum bioavailability. ${ }^{25}$

A large part of respondents, 100 from a total of 120 (83.33\%), answered that they always contact the prescriber before dentoalveolar surgery in patients treated with BPs. The result is similar to the one from the 2014 questionnaire $(82.86 \%)$. The percentage of those who never contact the prescriber before dental surgery has decreased only slightly, from $12.86 \%$ in 2014 to $11.67 \%$ in 2018 , and due to these unsupervised procedures, the patients' quality of life is compromised.

\section{CONCLUSIONS}

According to the findings of the present study, many of the respondent dentists have heard about BPs and related complications, but they are not aware of the fundamental concepts of BRONJ prevention and treatment protocols. Despite the limited size of the studied sample, the data are enough to affirm that the dentists' knowledge about BRONJ and the treatment of patients undergoing BP therapy improved over four years, but there are still many unknowns. The literature reveals many unknowns in the pathogenesis of the disease, and universal protocols are not established. Without appropriate protocols for prevention and treatment, the patients' quality of life is affected. Dentists should be more prepared regarding the treatment of these patients and they should be aware that conservative attitudes are the most suitable for patients with a history of BP treatment. A complete medical history of the patient must be recorded carefully, and the treatment should be analyzed after contacting the prescriber. Therefore, practical initiatives, such as lectures and workshops at conferences, or even flyers, should be taken seriously, to help strengthen knowledge in this domain. Preventing or minimizing the occurrence of BRONJ must be known among doctors who prescribe BPs, such as oncologists, endocrinologists, hematologists (referring patients to the dentist before starting a BP treatment), but to the same extent by maxillofacial surgeons or dentists whom the patient are addressing.

\section{CONFLICT OF INTEREST}

The authors declare no conflict of interests. 


\section{REFERENCES}

1. Marx RE. Pamidronate (Aredia) and zoledronate (Zometa) induced avascular necrosis of the jaws: A growing epidemic. J Oral Maxillofac Surg. 2003;61:1115-1117.

2. Ruggiero SL, Dodson TB, Assael LA, et al. American association of oral and maxillofacial surgeons position paper on bisphosphonaterelated osteonecrosis of the jaws-2009 update. J Oral Maxillofac Surg. 2009;67:2-12

3. Pittman K, Antill YC, Goldrick A, Goh J, de Boer RH. Denosumab: Prevention and management of hypocalcemia, osteonecrosis of the jaw and atypical fractures. Asia Pac J Clin Oncol. 2017;13:266-276.

4. Ruggiero SL, Mehrotra B, Rosenberg TJ, Engroff SL. Osteonecrosis of the jaws associated with the use of bisphosphonates: a review of 63 cases. $J$ Oral Maxillofac Surg. 2004;62:527-534.

5. Wood J, Bonjean K, Ruetz S, et al. Novel antiangiogenic effects of the bisphosphonate compound zoledronic acid. J Pharmacol Exp Ther. 2002;302:1055-1061

6. Yamashita J, McCauley LK. Antiresorptives and osteonecrosis of the jaw. J Evid Base Dent Pract. 2012:S1:233-247.

7. Saia G, Blandamura S, Bettini G, et al. Occurrence of bisphosphonaterelated osteonecrosis of the jaw after surgical tooth extraction. J Oral Maxillofac Surg. 2010;68:797-804.

8. Conte Neto N, Spolidorio LC, Andrade CR, Bastos S, Guimarães A, Marcantonio ME Jr. Experimental development of bisphosphonate-related osteonecrosis of the jaws in rodents. Int J Exp Pathol. 2013;94:65-73.

9. Marx RE, Sawatari Y, Fortin M, Broumand V. Bisphosphonate-Induced Exposed Bone (Osteonecrosis/Osteopetrosis) of the Jaws: Risk Factors, Recognition, Prevention, and Treatment. J Oral Maxillofac Surg. 2005;63:1567-1575

10. Kumar SK, Gorur A, Schaudinn C, Shuler CF, Costerton JW, Sedghizadeh PP. The role of microbial biofilms in osteonecrosis of the jaw associated with bisphosphonate therapy. Curr Osteoporos Rep. 2010;8:40-48.

11. Solomon DH, Mercer E, Woo SB, Avorn J, Schneeweiss S, Treister N. Defining the epidemiology of bisphosphonate-associated osteonecrosis of the jaw: prior work and current challenges. Osteoporosis International. 2013;24:237-244

12. Walter C, Al-Nawas B, Grotz KA, et al. Prevalence and risk factors of bisphosphonate-associated osteonecrosis of the jaw in prostate cancer patients with advanced disease treated with zoledronate. European Urology. 2008;54:1066-1072.
13. Badros A, Weikel D, Salama A, et al. Osteonecrosis of the jaw in multiple myeloma patients: Clinical features and risk factors. J Clin Oncol. 2006:24:945.

14. Ruggiero SL, Dodson TB, Fantasia J, et al. American Association of Oral and Maxillofacial Surgeons position paper on medication-related osteonecrosis of the jaw - 2014 update. J Oral Maxillofac Surg. 2014;72:1938-1956.

15. Albu IA, Petrovan C, Păcurar M, et al. Biophosphonate-Related Osteonecrosis of the Jaws: A Real Challenge for Dentists. Acta Medica Marisiensis. 2015;61:115-119.

16. Mercer E, Norton T, Woo S, Treister N, Dodson TB, Solomon DH. Ninety-one osteoporosis patients affected with bisphosphonate-related osteonecrosis of the jaw: a case series. Calcif Tissue Int. 2013;93:241-248.

17. Lazarovici TS, Yahalom R, Taicher S, Elad S, Hardan I, Yarom N. Bisphosphonate-related osteonecrosis of the jaws: a single-center study of 101 patients. J Oral Maxillofac Surg. 2009:67:850-855.

18. Nicolatou-Galitis O, Papadopoulou E, Sarri T, et al. Osteonecrosis of the jaw in oncology patients treated with bisphosphonates: prospective experience of a dental oncology referral center. Oral Surg Oral Med Ora Pathol Oral Radiol Endod. 2011:112:195-202.

19. Hallmer F, Bjørnland T, Nicklasson A, Becktor JP, Andersson G Osteonecrosis of the jaw in patients treated with oral and intravenous bisphosphonates: experience in Sweden. Oral Surg Oral Med Oral Patho Oral Radiol. 2014;118:202-208.

20. Bauer JS, Beck N, Kiefer J, Stockmann P, Wichmann M, Eitner S. Awareness and education of patients receiving bisphosphonates. J Craniomaxillofac Surg. 2012;40:277-282.

21. Allen MR, Burr DB. The pathogenesis of bisphosphonate-related osteonecrosis of the jaw: so many hypotheses, so few data. J Ora Maxillofac Surg. 2009;67:61-70.

22. Migliorati CA, Casiglia J, Epstein J, Jacobsen PL, Siegel MA, Woo SB. Managing the care of patients with bisphosphonate-associated osteonecrosis: an American Academy of Oral Medicine position paper. $J$ Am Dent Assoc. 2005:136:1658-1668.

23. Ji X, Pushalkar S, Li Y, Glickman R, Fleisher K, Saxena D. Antibiotic effects on bacterial profile in osteonecrosis of the jaw. Oral Dis. 2012:18:85-95.

24. Berti-Couto SA, Vasconcelos AC, Iglesias JE, Figueiredo MA, Salum FG Cherubini K. Diabetes mellitus and corticotherapy as risk factors for alendronate-related osteonecrosis of the jaws: a study in Wistar rats. Head Neck. 2014:36:84-93.

25. Drake MT, Clarke BL, Lewiecki EM. The Pathophysiology and Treatment of Osteoporosis. Clin Ther. 2015:37:1837-1850. 